Cellular Physiology
and Biochemistry and Biochemistry Published online: July 11, 2016

Accepted: June 13, 2016

This article is licensed under the Creative Commons Attribution-NonCommercial-NoDerivatives 4.0 International License (CC BY-NC-ND) (http://www.karger.com/Services/OpenAccessLicense). Usage and distribution for commercial purposes as well as any distribution of modified material requires written permission.

\title{
Stimulating Effect of Sclareol on Suicidal Death of Human Erythrocytes
}

\author{
Elena Signoretto ${ }^{a, c} \quad$ Stefan A. Laufer ${ }^{b} \quad$ Florian Lang ${ }^{a}$ \\ aDepartments of Cardiology, Cardiovascular Medicine and Physiology, as well as 'Institute of Pharmacy, \\ University of Tuebingen, Tuebingen, Germany; 'Department of Pharmacological and Biomolecular \\ Sciences, Università degli Studi di Milano, Milano, Italy
}

\section{Key Words}

Phosphatidylserine • Cell volume • Eryptosis • Skepinone • D4476 • Calcium • Sclareol

\begin{abstract}
Background/Aims: The diterpene alcohol Sclareol has been proposed for the treatment of malignancy. In analogy to apoptosis of nucleated cells, erythrocytes may enter eryptosis, a suicidal cell death characterized by cell shrinkage and cell membrane scrambling with phosphatidylserine translocation to the erythrocyte surface. Cellular mechanisms involved in the triggering of eryptosis include increase of cytosolic $\mathrm{Ca}^{2+}$ activity $\left(\left[\mathrm{Ca}^{2+}\right]_{\mathrm{i}}\right)$, oxidative stress, ceramide, p38 kinase and casein kinase $1 \alpha$. The present study explored, whether Sclareol induces eryptosis and, if so, shed light on the mechanisms involved. Methods: Phosphatidylserine abundance at the erythrocyte surface was estimated from annexin-V-binding, cell volume from forward scatter, $\left[\mathrm{Ca}^{2+}\right]_{\text {i }}$ from Fluo3-fluorescence, abundance of reactive oxygen species (ROS) from 2',7'-dichlorodihydrofluorescein diacetate (DCFDA)-dependent fluorescence, and ceramide abundance at the erythrocyte surface utilizing specific antibodies. Hemolysis was estimated from haemoglobin concentration in the supernatant. Results: A 48 hours exposure of human erythrocytes to Sclareol $(\geq 50 \mu \mathrm{M})$ significantly increased the percentage of annexin$V$-binding cells without significantly modifying the average forward scatter, DCF-fluorescence or ceramide abundance. Sclareol $(\geq 50 \mu \mathrm{M})$ further triggered hemolysis. Sclareol $(100 \mu \mathrm{M})$ significantly increased Fluo3-fluorescence, but the effect of Sclareol on annexin-V-binding was not significantly blunted by removal of extracellular $\mathrm{Ca}^{2+}$. Instead, the effect of Sclareol on annexin-V-binding was significantly blunted in the presence of p38 kinase inhibitor skepinone $(2 \mu \mathrm{M})$ and in the presence of casein kinase $1 \alpha$ inhibitor D4476 $(10 \mu \mathrm{M})$. Conclusions: Sclareol triggers phospholipid scrambling of the erythrocyte cell membrane, an effect in part due to activation of p38 kinase and casein kinase $1 \alpha$.




\section{Cellular Physiology Cell Physiol Biochem 2016;39:554-564 and Biochemistry Published online: July 11, $2016 \quad \begin{aligned} & \text { DOI: 10.1159/000445647 } 2016 \text { The Author(s). Published by S. Karger AG, Basel } \\ & \text { www.karger.com/cpb }\end{aligned}$ \\ Signoretto/Laufer/Lang: Sclareol-Induced Eryptosis}

\section{Introduction}

Plant-derived terpenoids [1] such as the diterpene alcohol Sclareol [2] are effective against cancer [1, 3-13], inflammation [1, 14, 15], and infection [16-18]. Sclareol further influences brain function [19-25]. The effect of Sclareol against cancer is partially due to stimulation of tumor cell apoptosis $[3-5,7,12,13,26]$. Sclareol is incorporated into phospholipid model membranes [27] and has been shown to suppress the formation of nitric oxide [15] and prostaglandin E2 [15].

In analogy to apoptosis of nucleated cells, erythrocytes may enter eryptosis, the suicidal erythrocyte death characterized by cell shrinkage [28] and cell membrane scrambling with phosphatidylserine translocation to the cell surface [29]. Cellular mechanisms accomplishing eryptosis include $\mathrm{Ca}^{2+}$ entry with increase of cytotosolic $\mathrm{Ca}^{2+}$ activity $\left(\left[\mathrm{Ca}^{2+}\right]_{\mathrm{i}}\right)[29]$, ceramide [30], caspases [29, 31, 32], as well as activation of casein kinase $1 \alpha$, Janus-activated kinase JAK3, protein kinase C, and/or p38 kinase [29]. Eryptosis is further triggered by pharmacological inhibition or genetic knockout of AMP activated kinase, cGMPdependent protein kinase, and PAK2 kinase [29], by oxidative stress [29], energy depletion [29] and diverse xenobiotics [29, 33-64]. Eryptosis is enhanced in several clinical conditions, such as dehydration [65], hyperphosphatemia [66], chronic kidney disease (CKD) [67-70], hemolytic-uremic syndrome [71], diabetes [72], hepatic failure [73], malignancy [29], sepsis [74], sickle-cell disease [29], beta-thalassemia [29], Hb-C and G6PD-deficiency [29], as well as Wilsons disease [75].

The present study analyzed Sclareol sensitivity of eryptosis. Human erythrocytes drawn from healthy volunteers were treated with Sclareol and phosphatidylserine surface abundance, cell volume, $\left[\mathrm{Ca}^{2+}\right]_{i}$, reactive oxygen species (ROS), and ceramide abundance determined by flow cytometry. Moreover, the effect of Sclareol on cell membrane scrambling was quantified in the presence or absence of extracellular $\mathrm{Ca}^{2+}$, of p38 kinase inhibitor skepinone and of casein kinase $1 \alpha$ inhibitor D4476.

\section{Materials and Methods}

Erythrocytes, solutions and chemicals

Fresh Li-Heparin-anticoagulated blood samples were kindly provided by the blood bank of the University of Tübingen. The study is approved by the ethics committee of the University of Tübingen (184/2003 V). The blood was centrifuged at $120 \mathrm{~g}$ for $20 \mathrm{~min}$ at $21^{\circ} \mathrm{C}$ and the platelets and leukocytes-containing supernatant was disposed. Erythrocytes were incubated in vitro at a hematocrit of $0.4 \%$ in Ringer solution containing (in $\mathrm{mM}$ ) $125 \mathrm{NaCl}, 5 \mathrm{KCl}, 1 \mathrm{MgSO}_{4}, 32 \mathrm{~N}$-2-hydroxyethylpiperazine-N-2-ethanesulfonic acid (HEPES; pH 7.4), 5 glucose, 1 $\mathrm{CaCl}_{2}$, at $37^{\circ} \mathrm{C}$ for 48 hours. Where indicated, erythrocytes were exposed for 48 hours to Sclareol (Sigma Aldrich, Hamburg, Germany). To test for an involvement of p38 kinase or casein kinase $1 \alpha$, erythrocytes were exposed for 48 hours to a combination of Sclareol and p38 kinase inhibitor skepinone [76] or casein kinase $1 \alpha$ inhibitor D4476 (Tocris bioscience, Bristol, UK), respectively.

\section{Annexin-V-binding and forward scatter}

After incubation under the respective experimental condition, a $100 \mu \mathrm{l}$ cell suspension was washed in Ringer solution containing $5 \mathrm{mM} \mathrm{CaCl}_{2}$ and then stained with Annexin-V-FITC (1:200 dilution; ImmunoTools, Friesoythe, Germany) in this solution at $37^{\circ} \mathrm{C}$ for 20 min under protection from light. The annexin-Vabundance at the erythrocyte surface was subsequently determined on a FACS Calibur (BD, Heidelberg, Germany). Annexin-V-binding was measured with an excitation wavelength of $488 \mathrm{~nm}$ and an emission wavelength of $530 \mathrm{~nm}$. A marker (M1) was placed to set an arbitrary threshold between annexin-V-binding cells and control cells. The same threshold was used for untreated and Sclareol treated erythrocytes.

Intracellular $\mathrm{Ca}^{2+}$

After incubation, erythrocytes were washed in Ringer solution and loaded with Fluo-3/AM (Biotium, Hayward, USA) in Ringer solution containing $5 \mu \mathrm{M}$ Fluo-3/AM. The cells were incubated at $37^{\circ} \mathrm{C}$ for 30 


\section{Cellular Physiology Cell Physiol Biochem 2016;39:554-564 \begin{tabular}{l|l} 
and Biochemistry Published online: July 11, 2016 & $\begin{array}{l}\text { D } 2016 \text { The Author(s). Published by S. Karger AG, Basel } \\
\text { www.karger.com/cpb }\end{array}$
\end{tabular} \\ Signoretto/Laufer/Lang: Sclareol-Induced Eryptosis}

min. $\mathrm{Ca}^{2+}$-dependent fluorescence intensity was measured with an excitation wavelength of $488 \mathrm{~nm}$ and an emission wavelength of $530 \mathrm{~nm}$ on a FACS Calibur.

Reactive oxygen species (ROS)

Oxidative stress was determined utilizing 2',7'-dichlorodihydrofluorescein diacetate (DCFDA). After incubation, a $100 \mu \mathrm{l}$ suspension of erythrocytes was washed in Ringer solution and stained with DCFDA (Sigma, Schnelldorf, Germany) in Ringer solution containing DCFDA at a final concentration of $10 \mu \mathrm{M}$. Erythrocytes were incubated at $37^{\circ} \mathrm{C}$ for $30 \mathrm{~min}$ in the dark and washed two times in Ringer solution. The DCFDA-loaded erythrocytes were resuspended in $200 \mu \mathrm{l}$ Ringer solution and ROS-dependent fluorescence intensity was measured at an excitation wavelength of $488 \mathrm{~nm}$ and an emission wavelength of $530 \mathrm{~nm}$ on a FACS Calibur (BD).

\section{Ceramide abundance}

For the determination of ceramide, a monoclonal antibody-based assay was used. To this end, cells were stained for 1 hour at $37^{\circ} \mathrm{C}$ with $1 \mu \mathrm{g} / \mathrm{ml}$ anti ceramide antibody (clone MID 15B4, Alexis, Grünberg, Germany) in PBS containing $0.1 \%$ bovine serum albumin (BSA) at a dilution of 1:10. The samples were washed twice with PBS-BSA. The cells were stained for 30 minutes with polyclonal fluorescein isothiocyanate (FITC) conjugated goat anti-mouse IgG and IgM specific antibody (Pharmingen, Hamburg, Germany) diluted 1:50 in PBS-BSA. Unbound secondary antibody was removed by repeated washing with PBS-BSA. The samples were analyzed by flow cytometric analysis with an excitation wavelength of $488 \mathrm{~nm}$ and an emission wavelength of $530 \mathrm{~nm}$. As a control, secondary antibody alone was used.

\section{Hemolysis}

For the determination of hemolysis, erythrocyte suspensions were centrifuged $10 \mathrm{~min}$ at $2000 \mathrm{rpm}$ RT and the supernatants harvested. As a measure of hemolysis, the hemoglobin ( $\mathrm{Hb})$ concentration of the supernatants was determined photometrically at $405 \mathrm{~nm}$. The absorption of the supernatant of erythrocytes lysed in distilled water was defined as $100 \%$ hemolysis.

\section{Statistics}

Data are expressed as arithmetic means \pm SEM. As indicated in the figure legends, statistical analysis was made using ANOVA with Tukey's test as post-test and $t$ test as appropriate. $\mathrm{n}$ denotes the number of different erythrocyte specimens studied. Since different erythrocyte specimens used in distinct experiments are differently susceptible to triggers of eryptosis, the same erythrocyte specimens have been used for control and experimental conditions.

\section{Results}

The present study explored whether Sclareol stimulates eryptosis, the suicidal erythrocyte death characterized by cell shrinkage and by phospholipid scrambling of the cell membrane with phosphatidylserine translocation to the cell surface.

Phosphatidylserine exposing erythrocytes were identified utilizing annexin-V-binding, as determined by flow cytometry. Prior to measurements, the erythrocytes were incubated for 48 hours in Ringer solution without or with Sclareol $(10-100 \mu \mathrm{M})$. As illustrated in Fig. 1, a 48 hours exposure to Sclareol increased the percentage of phosphatidylserine exposing erythrocytes, an effect reaching statistical significance at $100 \mu \mathrm{M}$ Sclareol.

Erythrocyte volume was estimated from forward scatter which was determined utilizing flow cytometry. Prior to measurements, the erythrocytes were again incubated for 48 hours in Ringer solution without or with Sclareol $(10-100 \mu \mathrm{M})$. As shown in Fig. 2, Sclareol did not significantly modify the average erythrocyte forward scatter, but at a concentration of $100 \mu \mathrm{M}$ significantly decreased the percentage of large erythrocytes (>800).

As shown in Fig. 3, Sclareol exposure was further followed by hemolysis, an effect reaching statistical significance at $50 \mu \mathrm{M}$ Sclareol. 
A

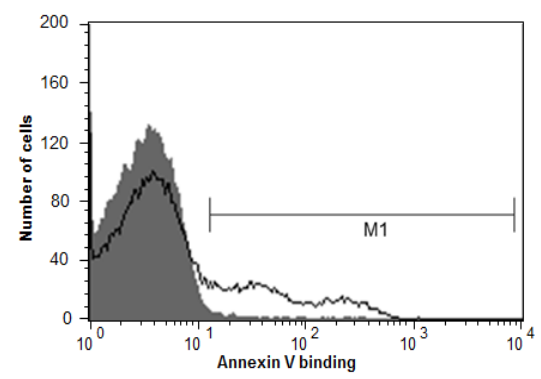

B

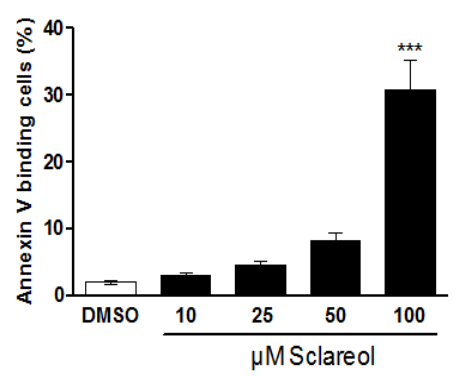

Fig. 1. Effect of Sclareol on phosphatidylserine exposure. A. Original histogram of annexin-V-binding of erythrocytes following exposure for 48 hours to Ringer solution without (grey area) and with (black line) presence of $100 \mu \mathrm{M}$ Sclareol. B. Arithmetic means \pm SEM $(n=10)$ of erythrocyte annexin-V-binding following incubation for 48 hours to Ringer solution without (white bar) or with (black bars) Sclareol (10 - 100 $\mu \mathrm{M}) .{ }^{* * *}(\mathrm{p}<0.001)$ indicates significant difference from the absence of Sclareol (ANOVA).

A

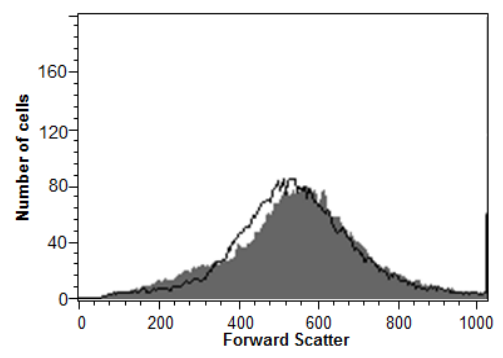

C

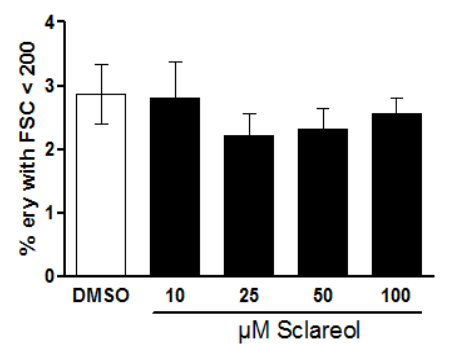

B

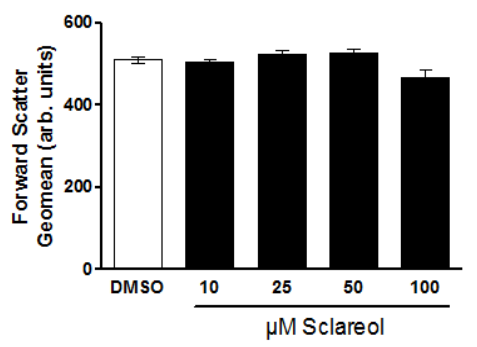

D

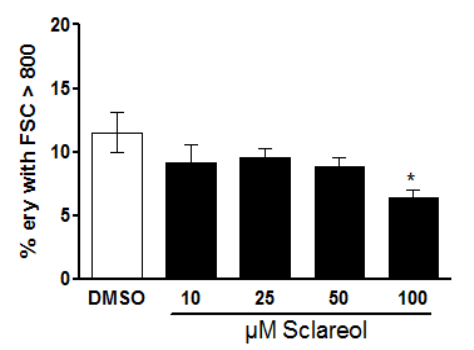

Fig. 2. Effect of Sclareol on erythrocyte forward scatter. A. Original histogram of forward scatter of erythrocytes following exposure for 48 hours to Ringer solution without (grey area) and with (black line) presence of $100 \mu \mathrm{M}$ Sclareol. B. Arithmetic means \pm SEM $(\mathrm{n}=10)$ of the erythrocyte forward scatter (FSC) following incubation for 48 hours to Ringer solution without (white bar) or with (black bars) Sclareol (10 - $100 \mu \mathrm{M})$. C. Arithmetic means \pm SEM $(n=10)$ of the percentage erythrocytes with forward scatter $(F S C)<200$ following incubation for 48 hours to Ringer solution without (white bar) or with (black bars) Sclareol $(10-100 \mu \mathrm{M})$. D. Arithmetic means \pm SEM $(n=10)$ of the percentage erythrocytes with forward scatter $(F S C)>800$ following incubation for 48 hours to Ringer solution without (white bar) or with (black bars) Sclareol (10 - 100 $\mu \mathrm{M}){ }^{*}(\mathrm{p}<0.05)$ indicates significant difference from the absence of Sclareol (ANOVA).

Fluo3-fluorescence was determined as a measure of cytosolic $\mathrm{Ca}^{2+}$ activity $\left(\left[\mathrm{Ca}^{2+}\right]_{\mathrm{i}}\right)$. As illustrated in Fig. 4, a 48 hours exposure to $100 \mu \mathrm{M}$ Sclareol significantly increased the Fluo3-fluorescence, an observation pointing to increase of $\left[\mathrm{Ca}^{2+}\right]_{i^{\text {. }}}$. 
Fig. 3. Effect of Sclareol on hemolysis. Arithmetic means \pm SEM $(n=10)$ of erythrocyte annexin-Vbinding following incubation for 48 hours to Ringer solution without (white bar) or with (black bars) Sclareol $(10-100 \mu \mathrm{M}) .{ }^{* *}(\mathrm{p}<0.01),{ }^{* * *}(\mathrm{p}<0.001)$ indicates significant difference from the absence of Sclareol (ANOVA).
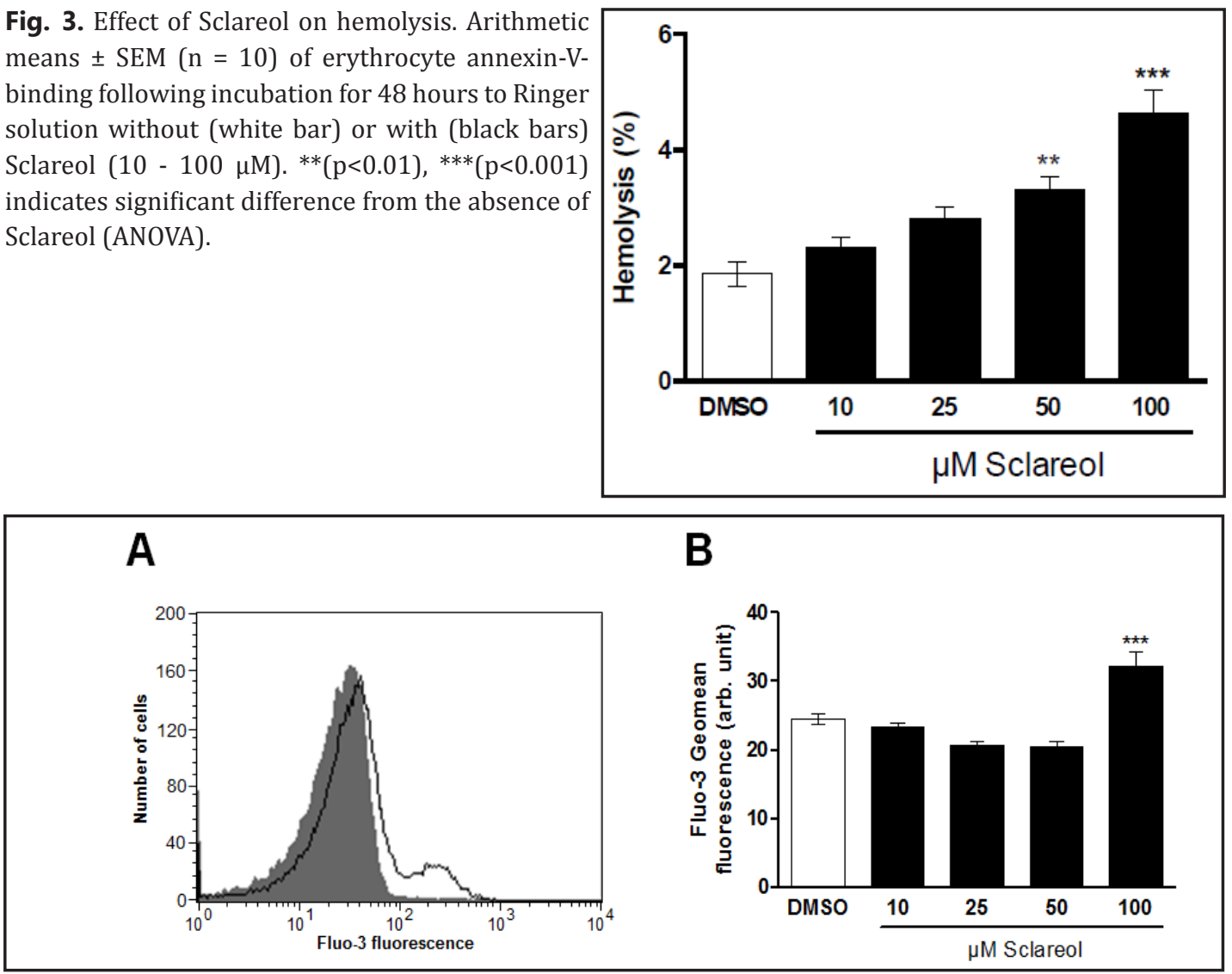

Fig. 4. Effect of Sclareol on cytosolic $\mathrm{Ca}^{2+}$ activity. A. Original histogram of Fluo3-fluorescence of erythrocytes following exposure for 48 hours to Ringer solution without (grey area) and with (black line) presence of $100 \mu \mathrm{M}$ Sclareol. B. Arithmetic means \pm SEM $(n=10)$ of erythrocyte annexin-V-binding following incubation for 48 hours to Ringer solution without (white bar) or with (black bars) Sclareol (10 - $100 \mu \mathrm{M})$. $* * *(\mathrm{p}<0.001)$ indicates significant difference from the absence of Sclareol (ANOVA).

In order to test, whether the Sclareol-induced translocation of phosphatidylserine was sensitive to extracellular $\mathrm{Ca}^{2+}$, erythrocytes were incubated for 48 hours in the absence or presence of 50 or $100 \mu \mathrm{M}$ Sclareol in the presence or nominal absence of extracellular $\mathrm{Ca}^{2+}$. As shown in Fig. 5, removal of extracellular $\mathrm{Ca}^{2+}$ did not significantly blunt the effect of Sclareol on the percentage of annexin-V-binding erythrocytes. Moreover, even in the absence of extracellular $\mathrm{Ca}^{2+}$, Sclareol significantly increased the percentage of annexin-V-binding erythrocytes. Thus, Sclareol-induced cell membrane scrambling was not dependent on entry of extracellular $\mathrm{Ca}^{2+}$.

Eryptosis is further stimulated by oxidative stress. Reactive oxygen species (ROS) were thus quantified utilizing $2^{\prime}, 7^{\prime}$-dichlorodihydrofluorescein (DCF) diacetate. As a result, the DCF-fluorescence was similar following exposure to $10 \mu \mathrm{M}$ Sclareol (15.1 \pm 0.4 a.u., $\mathrm{n}=5), 25$ $\mu \mathrm{M}$ Sclareol (13.6 \pm 0.6 a.u., $\mathrm{n}=5) 50 \mu \mathrm{M}$ Sclareol (12.8 \pm 0.4 a.u., $\mathrm{n}=5$ ) and $100 \mu \mathrm{M}$ Sclareol $(17.4 \pm 2.5$ a.u., $n=5)$ as in the absence of Sclareol (17.3 \pm 2.6 a.u., $n=5)$. Thus, Sclareol did not appreciably induce oxidative stress.

A further stimulator of eryptosis is ceramide. Ceramide abundance at the erythrocyte surface was thus quantified utilizing specific antibodies. As a result, the ceramide abundance was similar following exposure to $50 \mu \mathrm{M}$ Sclareol $(10.9 \pm 0.2$ a.u., $\mathrm{n}=5)$ and $100 \mu \mathrm{M}$ Sclareol $(11.4 \pm 0.2$ a.u., $\mathrm{n}=5)$ as in the absence of Sclareol (11.2 \pm 0.3 a.u., $\mathrm{n}=5)$. Thus, Sclareol did not appreciably induce ceramide abundance. 


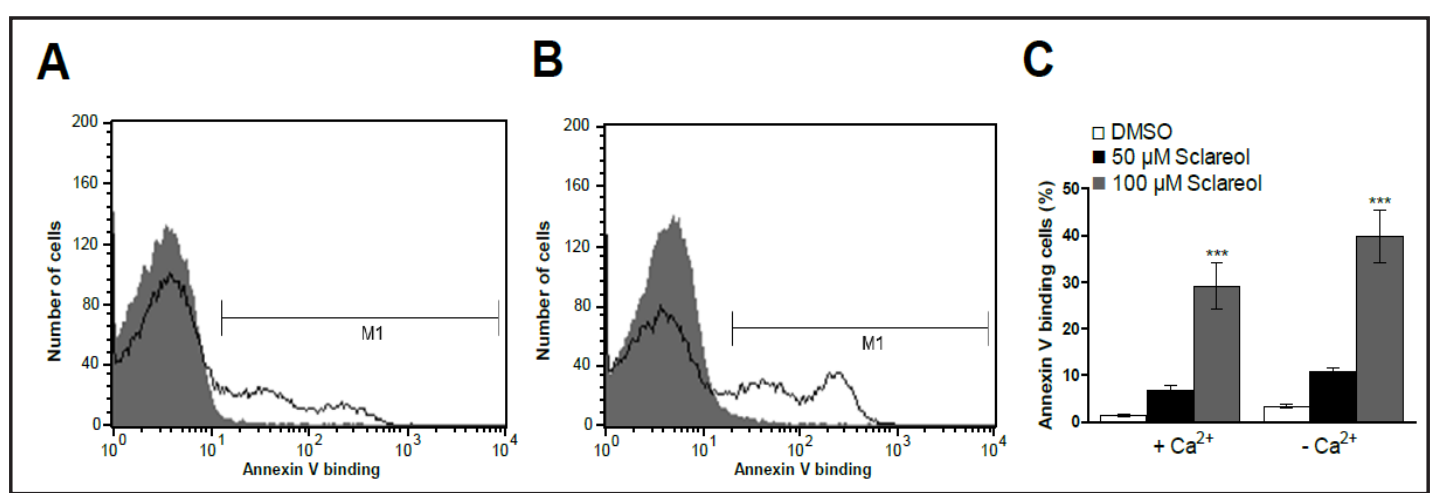

Fig. 5. $\mathrm{Ca}^{2+}$ sensitivity of Sclareol -induced phosphatidylserine exposure. A,B. Original histogram of annexinV-binding of erythrocytes following exposure for 48 hours to Ringer solution without (grey area) and with (black line) Sclareol $(100 \mu \mathrm{M})$ in the presence (A) and absence (B) of extracellular $\mathrm{Ca}^{2+}$. C. Arithmetic means \pm SEM ( $n=10$ ) of annexin-V-binding of erythrocytes after a 48 hours treatment with Ringer solution without (white bars) or with $50 \mu \mathrm{M}$ (black bars) or $100 \mu \mathrm{M}$ (grey bars) Sclareol in the presence (left bars, $+\mathrm{Ca}^{2+}$ ) and absence (right bars, $\left.-\mathrm{Ca}^{2+}\right)$ of $\mathrm{Ca}^{2+} .{ }^{* * *}(\mathrm{p}<0.001)$ indicates significant difference from the absence of Sclareol (ANOVA).

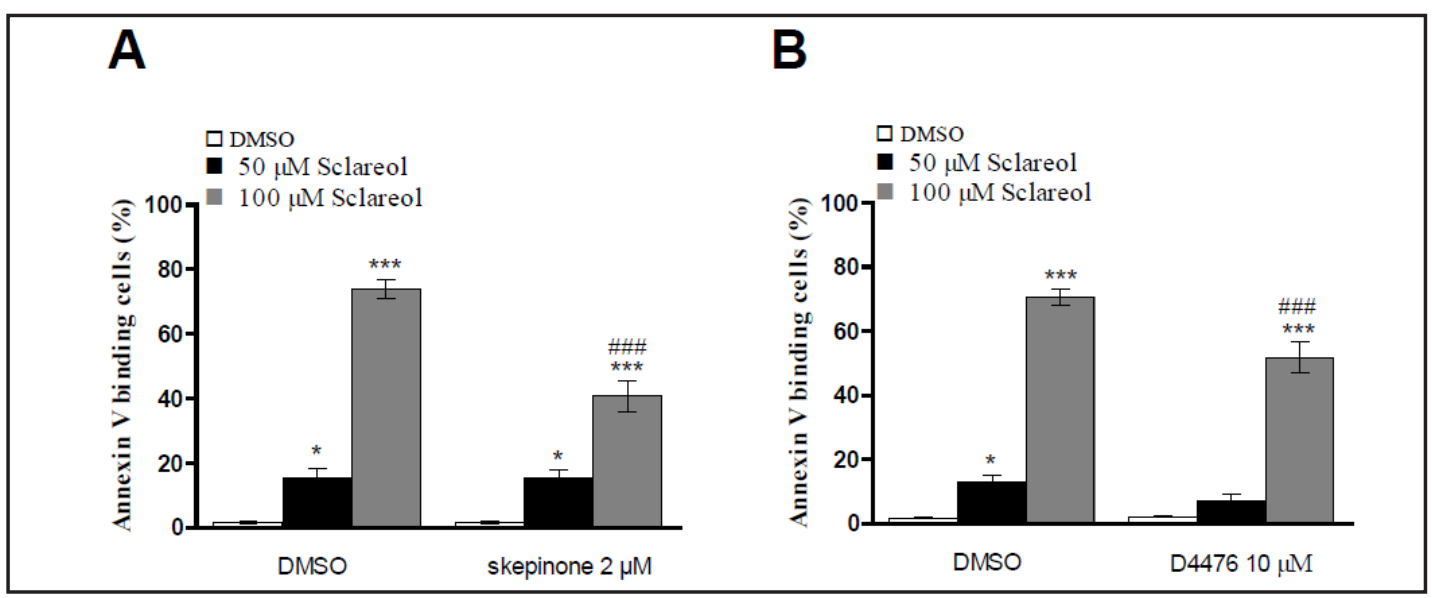

Fig. 6. Effect of p38 kinase inhibitor skepinone and of casein kinase $1 \alpha$ inhibitor D4476 on Sclareol -induced phosphatidylserine exposure. A. Arithmetic means \pm SEM $(n=10)$ of annexin-V-binding of erythrocytes after a 48 hours treatment with Ringer solution without (white bars) or with $50 \mu \mathrm{M}$ (black bars) or $100 \mu \mathrm{M}$ (grey bars) Sclareol in the absence (left bars, DMSO) and presence (right bars, skepinone) of p38 kinase inhibitor skepinone $(2 \mu \mathrm{M})$. B. Arithmetic means \pm SEM $(n=15)$ of annexin-V-binding of erythrocytes after a 48 hours treatment with Ringer solution without (white bars) or with $50 \mu \mathrm{M}$ (black bars) or $100 \mu \mathrm{M}$ (grey bars) Sclareol in the absence (left bars, DMSO) and presence (right bars, D4476) of casein kinase $1 \alpha$ inhibitor D4476 $(10 \mu \mathrm{M}) . *(\mathrm{p}<0.05),{ }^{* * *}(\mathrm{p}<0.001)$ indicates significant difference from the absence of Sclareol, \#\#\#(p<0.001) indicates significant difference from the absence of kinase inhibitors (ANOVA).

To explore, whether the effects of Sclareol involved p38 kinase activity, the influence of Sclareol on annexin-V-binding was tested in the absence or presence of p38 kinase inhibitor skepinone $(2 \mu \mathrm{M})$. As illustrated in Fig. $6 \mathrm{~A}$, the effect of $100 \mu \mathrm{M}$ Sclareol was significantly blunted in the presence of skepinone. However, even in the presence of skepinone, Sclareol significantly increased the percentage of annexin-V-binding erythrocytes. Thus, Sclareolinduced cell membrane scrambling was apparently in part but not fully due to activation of p38 kinase.

To explore, whether the effects of Sclareol required casein kinase $1 \alpha$ activity, the influence of Sclareol on annexin-V-binding was tested in the absence or presence of casein kinase $1 \alpha$ inhibitor D4476 $(10 \mu \mathrm{M})$. As illustrated in Fig. 6B, the effect of $100 \mu \mathrm{M}$ Sclareol KARGER 


\section{Cellular Physiology Cell Physiol Biochem 2016;39:554-564 \\ \begin{tabular}{c|c|c|} 
DOI: 10.1159/000445647 & O 2016 The Author(s). Published by S. Karger AG, Basel \\
www.karger.com/cpb
\end{tabular} \\ Signoretto/Laufer/Lang: Sclareol-Induced Eryptosis}

was significantly blunted in the presence of D4476. However, even in the presence of D4476, Sclareol significantly increased the percentage of annexin-V-binding erythrocytes. Thus, Sclareol-induced cell membrane scrambling was again in part but not fully due to activation of casein kinase $1 \alpha$.

\section{Discussion}

The present observations uncover a novel stimulator of erythrocyte cell membrane scrambling, i.e. the diterpene alcohol Sclareol. Treatment of erythrocytes from healthy individuals with Sclareol results in cell membrane scrambling with phosphatidylserine translocation to the erythrocyte surface.

The effect of $100 \mu \mathrm{M}$ Sclareol on cell membrane scrambling was paralleled by an increase of Fluo3-fluorescence, an observation pointing to increase of cytosolic $\mathrm{Ca}^{2+}$ activity $\left(\left[\mathrm{Ca}^{2+}\right]_{\mathrm{i}}\right)$. However, the effect on cell membrane scrambling was not significantly modified by removal of $\mathrm{Ca}^{2+}$ from extracellular space, indicating that the effect did not require entry of extracellular $\mathrm{Ca}^{2+}$. Moreover, the effect of Sclareol on cell membrane scrambling was not paralleled by oxidative stress and not by increased ceramide abundance at the erythrocyte surface. Instead, the effect of Sclareol on cell membrane scrambling was significantly blunted by pharmacological inhibition of p38 kinase and of casein kinase $1 \alpha$, both kinases known to be involved in the machinery stimulating eryptosis [29]. However, even in the presence of the respective kinase inhibitors, Sclareol significantly increased the percentage of annexin-V-binding erythrocytes, indicating that the stimulation of eryptosis by Sclareol may involve further cellular mechanisms. Those mechanisms could include activation of further kinases, such as protein kinase c or Janusactivated kinase JAK3, as well as inhibition of kinases, such as AMPK, cGMP-dependent protein kinase, and PAK2 kinase [29].

Despite a significant increase of $\left[\mathrm{Ca}^{2+}\right]_{i}$ following Sclareol treatment, Sclareol had no significant effect on the average forward scatter. An increase of $\left[\mathrm{Ca}^{2+}\right]_{i}$ were expected to activate $\mathrm{Ca}^{2+}$ sensitive $\mathrm{K}^{+}$channels leading to $\mathrm{K}^{+}$exit, cell membrane hyperpolarization, $\mathrm{Cl}^{-}$exit and thus cellular loss of $\mathrm{KCl}$ with water [28]. Possibly, the effect of $\mathrm{K}^{+}$channel activation on cell volume was abrogated by impairment of $\mathrm{Na}^{+} / \mathrm{K}^{+}$ATPase with respective dissipation of chemical $\mathrm{K}^{+}, \mathrm{Na}^{+}$ and $\mathrm{Cl}^{-}$grandients.

Besides its effect on cell membrane scrambling, Sclareol triggered hemolysis with release of hemoglobin, which may in vivo pass the renal glomerular filter, precipitate in the acidic lumen of renal tubules, occlude nephrons and thus cause renal failure [77]. To the extent that eryptosis precedes hemolysis, those consequences are prevented due to timely removal of the affected erythrocytes from circulating blood.

The loss of phosphatidylserine exposing erythrocytes may, however, lead to anemia as long as it is not compensated by stimulation of erythropoiesis with matching formation of new erythrocytes [29]. Phosphatidylserine exposing erythrocytes further bind to the vascular wall [78], trigger blood clotting and thus predispose to thrombosis [79-81]. Excessive eryptosis could thus impair microcirculation [30, 79, 82-85].

\section{Conclusion}

In conclusion, Sclareol triggers cell membrane scrambling, an effect partially dependent on activities of p38 kinase and casein kinase $1 \alpha$.

\section{Acknowledgements}

The authors acknowledge the meticulous preparation of the manuscript by Tanja Loch. The study was supported by the Deutsche Forschungsgemeinschaft.

\section{KARGER}




\section{Cellular Physiology Cell Physiol Biochem 2016;39:554-564 \begin{tabular}{l|l} 
and Biochemistry 10.1159/000445647 & $\begin{array}{l}\text { D 2016 The Author(s). Published by S. Karger AG, Basel } \\
\text { www.karger.com/cpb }\end{array}$
\end{tabular} \\ Signoretto/Laufer/Lang: Sclareol-Induced Eryptosis}

Disclosure Statement

The authors of this manuscript state that they have no conflicts of interest to declare.

\section{References}

1 Sultana N, Saify ZS: Enzymatic biotransformation of terpenes as bioactive agents. J Enz Inhibit Medi Chem 2013;28:1113-1128.

2 Zerbe P, Bohlmann J: Enzymes for Synthetic Biology of Ambroxide-Related Diterpenoid Fragrance Compounds. Adv Biochem Eng Biotechnol 2015;148:427-447.

3 Dimas K, Hatziantoniou S, Tseleni S, Khan H, Georgopoulos A, Alevizopoulos K, Wyche JH, Pantazis P, Demetzos C: Sclareol induces apoptosis in human HCT116 colon cancer cells in vitro and suppression of HCT116 tumor growth in immunodeficient mice. Apoptosis 2007;12:685-694.

4 Dimas K, Kokkinopoulos D, Demetzos C, Vaos B, Marselos M, Malamas M, Tzavaras T: The effect of sclareol on growth and cell cycle progression of human leukemic cell lines. Leukemia Res 1999;23:217-234.

5 Dimas K, Papadaki A, Tsimplouli C, Hatziantoniou S, Alevizopoulos K, Pantazis P, Demetzos C: Labd-14-ene8,13-diol (sclareol) induces cell cycle arrest and apoptosis in human breast cancer cells and enhances the activity of anticancer drugs. Biomed Pharmacother 2006;60:127-133.

6 Hatziantoniou S, Dimas K, Georgopoulos A, Sotiriadou N, Demetzos C: Cytotoxic and antitumor activity of liposome-incorporated sclareol against cancer cell lines and human colon cancer xenografts. Pharmacol Res 2006;53:80-87.

7 Mahaira LG, Tsimplouli C, Sakellaridis N, Alevizopoulos K, Demetzos C, Han ZY, Pantazis P, Dimas K: The labdane diterpene sclareol (labd-14-ene-8, 13-diol) induces apoptosis in human tumor cell lines and suppression of tumor growth in vivo via a p53-independent mechanism of action. Eur J Pharmacol 2011;666:173-182.

8 Noori S, Hassan ZM, Mohammadi M, Habibi Z, Sohrabi N, Bayanolhagh S: Sclareol modulates the Treg intratumoral infiltrated cell and inhibits tumor growth in vivo. Cell Immunol 2010;263:148-153.

9 Noori S, Hassan ZM, Salehian O: Sclareol Reduces CD4+CD25+FoxP3+T-reg Cells in a Breast Cancer Model in Vivo. Iran J Immunol 2013;10:10-21.

10 Paradissis A, Hatziantoniou S, Georgopoulos A, Psarra AMG, Dimas K, Demetzos C: Liposomes modify the subcellular distribution of sclareol uptake by HCT-116 cancer cell lines. Biomed Pharmacother 2007;61:120-124.

11 Sashidhara KV, Rosaiah JN, Kumar A, Bid HK, Konwar R, Chattopadhyay N: Cell growth inhibitory action of an unusual labdane diterpene, 13-epi-Sclareol in breast and uterine cancers in vitro. Phytother Res 2007;21:1105-1108.

12 Shakeel-u-Rehman, Rah B, Lone SH, Rasool RU, Farooq S, Nayak D, Chikan NA, Chakraborty S, Behl A, Mondhe DM, Goswami A, Bhat KA: Design and Synthesis of Antitumor Heck-Coupled Sclareol Analogues: Modulation of BH3 Family Members by SS-12 in Autophagy and Apoptotic Cell Death. J Med Chem 2015;58:3432-3444.

13 Wang L, He HS, Yu HL, Zeng Y, Han H, He N, Liu ZG, Wang ZY, Xu SJ, Xiong M: Sclareol, a plant diterpene, exhibits potent antiproliferative effects via the induction of apoptosis and mitochondrial membrane potential loss in osteosarcoma cancer cells. Mol Med Reports 2015;11:4273-4278.

14 Huang GJ, Pan CH, Wu CH: Sclareol Exhibits Anti-inflammatory Activity in Both LipopolysaccharideStimulated Macrophages and the lambda-Carrageenan-Induced Paw Edema Model. J Nat Prod 2012;75:5459.

15 Zhong Y, Huang Y, Santoso MB, Wu LD: Sclareol exerts anti-osteoarthritic activities in interleukin-1 beta-induced rabbit chondrocytes and a rabbit osteoarthritis model. International J Clin Exp Pathol 2015;8:2365-2374.

16 Choudhary ML, Siddiqui ZA, Hussain S, Atta-ur-Rahman: Structure elucidation and antibacterial activity of new fungal metabolites of sclareol. Chem Biodivers 2006;3:54-61.

17 Ma MF, Feng JL, Li RX, Chen SW, Xu H: Synthesis and antifungal activity of ethers, alcohols, and iodohydrin derivatives of sclareol against phytopathogenic fungi in vitro. Bioorg Med Chem Lett 2015;25:2773-2777. 


\section{Cellular Physiology Cell Physiol Biochem 2016;39:554-564 \begin{tabular}{l|l|l|}
\hline DOI: 10.1159/000445647 & $\begin{array}{l}\text { C) } 2016 \text { The Author(s). Published by S. Karger AG, Basel } \\
\text { www.karger.com/cpb }\end{array}$
\end{tabular} \\ Signoretto/Laufer/Lang: Sclareol-Induced Eryptosis}

18 Tapia L, Torres J, Mendoza L, Urzua A, Ferreira J, Pavani M, Wilkens M: Effect of 13-epi-sclareol on the bacterial respiratory chain. Planta Med 2004;70:1058-1063.

19 Georgieva J: Effects of the Diterpene Sclareol Glycol on Body-Temperature in Rats. Methods Find Exp Clin Pharmacol 1989;11:277-280.

20 Georgieva J: Effects of the Diterpene Sclareol Glycol on Convulsive Seizures. Methods Find Exp Clin Pharmacol 1989;11:335-340.

21 Georgieva J: Measures of Anxiety, Retention and Stress in the Rat Following Treatment with the Diterpene Sclareol Glycol. Methods Find Exp Clin Pharmacol 1990;12:5-10.

22 Georgieva J: The Response of Diterpene Sclareol Glycol to Acute-Hypoxia in Mice. Methods Find Exp Clin Pharmacol 1990;12:591-593.

23 Georgieva J, Danchev N: The Effects of the Diterpene Sclareol Glycol on Seizures Do Not Depend on Central Benzodiazepine Receptors. Methods Find Exp Clin Pharmacol 1990;12:679-683.

24 Georgieva JV: Diterpene Sclareol Glycol Inhibits Clonidine-Induced Aggressive Responses in Mice. Pharmacol Biochem Behav 1989;34:503-505.

25 Georgieva JV: Influences of Diterpene Sclareol Glycol on Some Dopamine Related Behavior. Gen Pharmacol 1991;22:331-335.

26 Patel NR, Hatziantoniou S, Georgopoulos A, Demetzos C, Torchilin VP, Weissig V, D'Souza GGM: Mitochondria-targeted liposomes improve the apoptotic and cytotoxic action of sclareol. J Liposome Res 2010;20:244-249.

27 Kyrikou I, Georgopoulos A, Hatziantoniou S, Mavromoustakos T, Demetzos C: A comparative study of the effects of cholesterol and sclareol, a bioactive labdane type diterpene, on phospholipid bilayers. Chem Phys Lipids 2005;133:125-134.

28 Lang PA, Kaiser S, Myssina S, Wieder T, Lang F, Huber SM: Role of Ca2+-activated K+ channels in human erythrocyte apoptosis. Am J Physiol Cell Physiol 2003;285:C1553-C1560.

29 Lang E, Lang F: Mechanisms and pathophysiological significance of eryptosis, the suicidal erythrocyte death. Semin Cell Dev Biol 2015;39:35-42.

30 Abed M, Towhid ST, Mia S, Pakladok T, Alesutan I, Borst O, Gawaz M, Gulbins E, Lang F: Sphingomyelinaseinduced adhesion of eryptotic erythrocytes to endothelial cells. Am J Physiol Cell Physiol 2012;303:C991999.

31 Lau IP, Chen H, Wang J, Ong HC, Leung KC, Ho HP, Kong SK: In vitro effect of CTAB- and PEG-coated gold nanorods on the induction of eryptosis/erythroptosis in human erythrocytes. Nanotoxicology 2012;6:847856.

32 Maellaro E, Leoncini S, Moretti D, Del Bello B, Tanganelli I, De Felice C, Ciccoli L: Erythrocyte caspase-3 activation and oxidative imbalance in erythrocytes and in plasma of type 2 diabetic patients. Acta Diabetol 2013;50:489-495.

33 Alzoubi K, Calabròa S, Bissinger R, Abed M, Faggio C, Lang F: Stimulation of Suicidal Erythrocyte Death by Artesunate. Cell Physiol Biochem 2014;34:2232-2244.

34 Alzoubi K, Egler J, Abed M, Lang F: Enhanced Eryptosis Following Auranofin Exposure. Cell Physiol Biochem 2015;37:1018-1028.

35 Arnold M, Bissinger R, Lang F: Mitoxantrone-induced suicidal erythrocyte death. Cell Physiol Biochem 2014;34:1756-1767.

36 Arnold M, Lang E, Modicano P, Bissinger R, Faggio C, Abed M, Lang F: Effect of nitazoxanide on erythrocytes. Basic Clin Pharmacol Toxicol 2014;114:421-426.

37 Bissinger R, Barking S, Alzoubi K, Liu G, Liu G, Lang F: Stimulation of Suicidal Erythrocyte Death by the Antimalarial Drug Mefloquine. Cell Physiol Biochem 2015;36:1395-1405.

38 Bissinger R, Bouguerra G, Stockinger K, Abbes S, Lang F: Triggering of Suicidal Erythrocyte Death by Topotecan. Cell Physiol Biochem 2015;37:1607-1618.

39 Bissinger R, Fischer S, Jilani K, Lang F: Stimulation of Erythrocyte Death by Phloretin. Cell Physiol Biochem 2014;34:2256-2265.

40 Bissinger R, Lupescu A, Zelenak C, Jilani K, Lang F: Stimulation of eryptosis by cryptotanshinone. Cell Physiol Biochem 2014;34:432-442.

41 Bouguerra G, Aljanadi O, Bissinger R, Abbes S, Lang F: Embelin-Induced Phosphatidylserine Translocation in the Erythrocyte Cell Membrane. Cell Physiol Biochem 2015;37:1629-1640. 


\section{Cellular Physiology Cell Physiol Biochem 2016;39:554-564 \begin{tabular}{l|l|l|}
\hline DOI: 10.1159/000445647 & $\begin{array}{l}\text { C } 2016 \text { The Author(s). Published by S. Karger AG, Basel } \\
\text { www.karger.com/cpb }\end{array}$
\end{tabular} \\ Signoretto/Laufer/Lang: Sclareol-Induced Eryptosis}

42 Bouguerra G, Bissinger R, Abbes S, Lang F: Stimulation of Eryptosis by Narasin. Cell Physiol Biochem 2015;37:1807-1816.

43 Bouguerra G, Bissinger R, Abbes S, Lang F: Zopolrestat Induced Suicidal Death of Human Erythrocytes. Cell Physiol Biochem 2015;37:1537-1546.

44 Briglia M, Fazio A, Faggio C, Laufer S, Alzoubi K, Lang F: Triggering of Suicidal Erythrocyte Death by Ruxolitinib. Cell Physiol Biochem 2015;37:768-778.

45 Briglia M, Fazio A, Signoretto E, Faggio C, Lang F: Edelfosine Induced Suicidal Death of Human Erythrocytes. Cell Physiol Biochem 2015;37:2221-2230.

46 Calabro S, Alzoubi K, Faggio C, Laufer S, Lang F: Triggering of Suicidal Erythrocyte Death Following Boswellic Acid Exposure. Cell Physiol Biochem 2015;37:131-142.

47 Egler J, Lang F: Licochalcone A Induced Suicidal Death of Human Erythrocytes. Cell Physiol Biochem 2015;37:2060-2070.

48 Faggio C, Alzoubi K, Calabro S, Lang F: Stimulation of suicidal erythrocyte death by PRIMA-1. Cell Physiol Biochem 2015;35:529-540.

49 Fazio A, Briglia M, Faggio C, Alzoubi K, Lang F: Stimulation of Suicidal Erythrocyte Death by Garcinol. Cell Physiol Biochem 2015;37:805-815.

50 Jacobi J, Lang E, Bissinger R, Frauenfeld L, Modicano P, Faggio C, Abed M, Lang F: Stimulation of erythrocyte cell membrane scrambling by mitotane. Cell Physiol Biochem 2014;33:1516-1526.

51 Lang E, Jilani K, Bissinger R, Rexhepaj R, Zelenak C, Lupescu A, Lang F, Qadri SM: Vitamin D-Rich Diet in Mice Modulates Erythrocyte Survival. Kidney Blood Press Res 2015;40:403-412.

52 Lang E, Zelenak C, Eberhard M, Bissinger R, Rotte A, Ghashghaeinia M, Lupescu A, Lang F, Qadri SM: Impact of Cyclin-Dependent Kinase CDK4 Inhibition on Eryptosis. Cell Physiol Biochem 2015;37:1178-1186.

53 Lupescu A, Bissinger R, Goebel T, Salker MS, Alzoubi K, Liu G, Chirigiu L, Mack AF, Qadri SM, Lang F: Enhanced suicidal erythrocyte death contributing to anemia in the elderly. Cell Physiol Biochem 2015;36:773-783.

54 Lupescu A, Bissinger R, Herrmann T, Oswald G, Jilani K, Lang F: Induction of suicidal erythrocyte death by novobiocin. Cell Physiol Biochem 2014;33:670-680.

55 Lupescu A, Bissinger R, Warsi J, Jilani K, Lang F: Stimulation of erythrocyte cell membrane scrambling by gedunin. Cell Physiol Biochem 2014;33:1838-1848.

56 Malik A, Bissinger R, Calabro S, Faggio C, Jilani K, Lang F: Aristolochic Acid Induced Suicidal Erythrocyte Death. Kidney Blood Press Res 2014;39:408-419.

57 Officioso A, Alzoubi K, Manna C, Lang F: Clofazimine Induced Suicidal Death of Human Erythrocytes. Cell Physiol Biochem 2015;37:331-341.

58 Oswald G, Alzoubi K, Abed M, Lang F: Stimulation of suicidal erythrocyte death by ribavirin. Basic Clin Pharmacol Toxicol 2014;114:311-317.

59 Peter T, Bissinger R, Enkel S, Alzoubi K, Oswald G, Lang F: Programmed erythrocyte death following in vitro Treosulfan treatment. Cell Physiol Biochem 2015;35:1372-1380.

60 Stockinger K, Bissinger R, Bouguerra G, Abbes S, Lang F: Enhanced Eryptosis Following Exposure to Carnosic Acid. Cell Physiol Biochem 2015;37:1779-1791.

61 Tesoriere L, Attanzio A, Allegra M, Cilla A, Gentile C, Livrea MA: Oxysterol mixture in hypercholesterolemiarelevant proportion causes oxidative stress-dependent eryptosis. Cell Physiol Biochem 2014;34:10751089.

62 Waibel S, Bissinger R, Bouguerra G, Abbes S, Lang F: Saquinavir Induced Suicidal Death of Human Erythrocytes. Cell Physiol Biochem 2015;37:1973-1982.

63 Zierle J, Bissinger R, Egler J, Lang F: Lapatinib Induced Suicidal Death of Human Erythrocytes. Cell Physiol Biochem 2015;37:2275-2287.

64 Pagano M, Faggio C: The use of erythrocyte fragility to assess xenobiotic cytotoxicity. Cell Biochem Funct 2015;33:351-355.

65 Abed M, Feger M, Alzoubi K, Pakladok T, Frauenfeld L, Geiger C, Towhid ST, Lang F: Sensitization of erythrocytes to suicidal erythrocyte death following water deprivation. Kidney Blood Press Res 2013;37:567-578.

66 Voelkl J, Alzoubi K, Mamar AK, Ahmed MS, Abed M, Lang F: Stimulation of suicidal erythrocyte death by increased extracellular phosphate concentrations. Kidney Blood Press Res 2013;38:42-51. 


\section{Cellular Physiology Cell Physiol Biochem 2016;39:554-564 \begin{tabular}{l|l} 
DOI: 10.1159/000445647 & $\begin{array}{l}\text { O 2016 The Author(s). Published by S. Karger AG, Basel } \\
\text { www.karger.com/cpb }\end{array}$
\end{tabular} \\ Signoretto/Laufer/Lang: Sclareol-Induced Eryptosis}

67 Abed M, Artunc F, Alzoubi K, Honisch S, Baumann D, Foller M, Lang F: Suicidal erythrocyte death in endstage renal disease. J Mol Med (Berl) 2014;92:871-879.

68 Ahmed MS, Langer H, Abed M, Voelkl J, Lang F: The uremic toxin acrolein promotes suicidal erythrocyte death. Kidney Blood Press Res 2013;37:158-167.

69 Polak-Jonkisz D, Purzyc L: Ca(2+) influx versus efflux during eryptosis in uremic erythrocytes. Blood Purif 2012;34:209-210; author reply 210.

70 Calderon-Salinas JV, Munoz-Reyes EG, Guerrero-Romero JF, Rodriguez-Moran M, Bracho-Riquelme RL, Carrera-Gracia MA, Quintanar-Escorza MA: Eryptosis and oxidative damage in type 2 diabetic mellitus patients with chronic kidney disease. Mol Cell Biochem 2011;357:171-179.

71 Lang PA, Beringer O, Nicolay JP, Amon O, Kempe DS, Hermle T, Attanasio P, Akel A, Schafer R, Friedrich B, Risler T, Baur M, Olbricht CJ, Zimmerhackl LB, Zipfel PF, Wieder T, Lang F: Suicidal death of erythrocytes in recurrent hemolytic uremic syndrome. J Mol Med (Berl) 2006;84:378-388.

72 Nicolay JP, Schneider J, Niemoeller OM, Artunc F, Portero-Otin M, Haik G, Jr., Thornalley PJ, Schleicher E, Wieder T, Lang F: Stimulation of suicidal erythrocyte death by methylglyoxal. Cell Physiol Biochem 2006;18:223-232.

73 Lang E, Gatidis S, Freise NF, Bock H, Kubitz R, Lauermann C, Orth HM, Klindt C, Schuier M, Keitel V, Reich M, Liu G, Schmidt S, Xu HC, Qadri SM, Herebian D, Pandyra AA, Mayatepek E, Gulbins E, Lang F, Haussinger D, Lang KS, Foller M, Lang PA: Conjugated bilirubin triggers anemia by inducing erythrocyte death. Hepatology 2015;61:275-284.

74 Kempe DS, Akel A, Lang PA, Hermle T, Biswas R, Muresanu J, Friedrich B, Dreischer P, Wolz C, Schumacher U, Peschel A, Gotz F, Doring G, Wieder T, Gulbins E, Lang F: Suicidal erythrocyte death in sepsis. J Mol Med (Berl) 2007;85:273-281.

75 Lang PA, Schenck M, Nicolay JP, Becker JU, Kempe DS, Lupescu A, Koka S, Eisele K, Klarl BA, Rubben H, Schmid KW, Mann K, Hildenbrand S, Hefter H, Huber SM, Wieder T, Erhardt A, Haussinger D, Gulbins E, Lang F: Liver cell death and anemia in Wilson disease involve acid sphingomyelinase and ceramide. Nat Med 2007;13:164-170.

76 Koeberle SC, Romir J, Fischer S, Koeberle A, Schattel V, Albrecht W, Grutter C, Werz O, Rauh D, Stehle T, Laufer SA: Skepinone-L is a selective p38 mitogen-activated protein kinase inhibitor. Nature Chemical Biology 2012;8:141-143.

77 Harrison HE, Bunting H, Ordway NK, Albrink WS: The Pathogenesis of the Renal Injury Produced in the Dog by Hemoglobin or Methemoglobin. J Exp Med 1947;86:339-356.

78 Borst O, Abed M, Alesutan I, Towhid ST, Qadri SM, Foller M, Gawaz M, Lang F: Dynamic adhesion of eryptotic erythrocytes to endothelial cells via CXCL16/SR-PSOX. Am J Physiol Cell Physiol 2012;302:C644-C651.

79 Andrews DA, Low PS: Role of red blood cells in thrombosis. Curr Opin Hematol 1999;6:76-82.

80 Chung SM, Bae ON, Lim KM, Noh JY, Lee MY, Jung YS, Chung JH: Lysophosphatidic acid induces thrombogenic activity through phosphatidylserine exposure and procoagulant microvesicle generation in human erythrocytes. Arterioscler Thromb Vasc Biol 2007;27:414-421.

81 Zwaal RF, Comfurius P, Bevers EM: Surface exposure of phosphatidylserine in pathological cells. Cell Mol Life Sci 2005;62:971-988.

82 Closse C, Dachary-Prigent J, Boisseau MR: Phosphatidylserine-related adhesion of human erythrocytes to vascular endothelium. Br J Haematol 1999;107:300-302.

83 Gallagher PG, Chang SH, Rettig MP, Neely JE, Hillery CA, Smith BD, Low PS: Altered erythrocyte endothelial adherence and membrane phospholipid asymmetry in hereditary hydrocytosis. Blood 2003;101:46254627.

84 Pandolfi A, Di Pietro N, Sirolli V, Giardinelli A, Di Silvestre S, Amoroso L, Di Tomo P, Capani F, Consoli A, Bonomini M: Mechanisms of uremic erythrocyte-induced adhesion of human monocytes to cultured endothelial cells. J Cell Physiol 2007;213:699-709.

85 Wood BL, Gibson DF, Tait JF: Increased erythrocyte phosphatidylserine exposure in sickle cell disease: flowcytometric measurement and clinical associations. Blood 1996;88:1873-1880. 